\title{
Incorporação de práticas letradas na alfabetização
}

Angélica Sepúlveda ${ }^{1}$

Pesquisadora do Laboratório de Educação. Doutora em Psicologia da Educação pela Universidade de Barcelona.

Colaboradora externa do Grupo de Pesquisa em Escritura e Linguagem (GREL), dirigido pela Profa. Dra. Ana Teberosky.
Resumo: A pesquisa documenta a compreensão e uso, por parte de quatro professoras alfabetizadoras, de um dos materiais distribuídos pelo MEC para o ensino e a aprendizagem inicial da leitura, da escrita e da oralidade. A caracterização inicial do perfil das professoras revelou que essas têm uma escassa compreensão dos desafios conceituais que a cultura escrita supõe. Os resultados obtidos a partir do uso de tais materiais educativos sugerem que esses podem contribuir para a melhoria de práticas alfabetizadoras. As análises realizadas evidenciaram mudanças importantes no discurso das quatro professoras, sendo que a principal dificuldade observada se relacionou com as representações delas sobre os processos de ensino e aprendizagem. As concepções pouco construtivas sobre os processos de aprendizagem limitaram os resultados que poderiam ser obtidos com o uso do material complementar distribuído pelo MEC.

Palavras-chave: Práticas letradas. Alfabetização. Materiais complementares. 


\section{INTRODUÇÃO}

$\mathrm{Na}$ atualidade, existe um consenso acadêmico sobre a importância da atividade de leitura compartilhada de histórias para o desenvolvimento da linguagem e a aprendizagem da leitura e da escrita. Para diversas associações científicas e de profissionais da linguagem e da aprendizagem essa prática tem se constituído em um indicador de possível sucesso escolar (INTERNATIONAL READING ASSOCIATION AND NATIONAL ASSOCIATION FOR THE EDUCATION OF YOUNG CHILDREN, 1998). Por isso, ela é divulgada como uma das melhores práticas durante a alfabetização inicial (NATIONAL COUNCIL OF TEACHERS OF ENGLISH, 2004) e considerada uma atividade de promoção do desenvolvimento linguístico e da prevenção do surgimento de dificuldades na aprendizagem inicial da leitura e da escrita (AMERICAN SPEECH-LANGUAGE-HEARING ASSOCIATION, 2001).

Também no âmbito social, cada vez é mais frequente a defesa e promoção da atividade de leitura de livros de literatura infantil desde a mais tenra idade. Em espaços urbanos tem se tornado comum que bibliotecas, museus, livrarias, associações, etc., ofereçam a crianças e jovens oportunidades para terem encontros significativos com livros e leitores. Sem dúvida, o acúmulo de múltiplas evidências empíricas sobre a importância do texto como unidade de compreensão e produção da linguagem oral e escrita tem contribuído para essa opção pela promoção, nos contextos de socialização inicial, de práticas letradas ou de criação de contextos de cultura escrita (FERREIRO, 2001; TEBEROSKY, 2001).

Espera-se que nessas práticas que envolvem os textos escritos as crianças tenham diversas oportunidades para atribuir significados aos textos segundo as suas competências (TEBEROSKY, 2001), que visualizem os textos e reparem nas suas características gráficas e de formato; que ouçam textos lidos em voz alta e falem sobre eles, os parafraseiem, comentem, resumam, recontem, citem, reformulem ou contem de novo, etc. (TEBEROSKY; SEPÚLVEDA, 2008; SEPÚLVEDA; TEBEROSKY, 2011). Isso é, espera-se que os alunos fiquem imersos na oralidade secundária (ONG, 1987), nas formas e nos usos da linguagem relacionados com os textos escritos.

Os estudiosos dos efeitos da alfabetização na cognição humana sustentam que o avanço cognitivo resulta da possibilidade de participar em certo tipo de discurso: o discurso letrado ou discurso sobre os textos (HEATH, 1986; OLSON; ASTINGTON, 1990). Assim, as práticas letradas desde o início da alfabetização 
ajudam os aprendizes a ter acesso à forma como funciona o texto escrito, a aprender sua estrutura, a conhecer as formas próprias da linguagem que se escreve e suas funções, e tudo isto porque durante as atividades de leitura e de escrita de textos se geram os comentários para refletir sobre a linguagem e sobre o mundo a que refere (TEBEROSKY, 2001, 2011).

Assim, a atividade de leitura de livros para crianças, na alfabetização inicial, é importante porque cria oportunidades para falar sobre os textos. É nessa fala para referir, comentar, analisar, descrever, questionar, interpretar os textos, que se torna necessário pensar sobre a linguagem, em geral, e sobre a linguagem escrita, em particular (OLSON; ASTINGTON, 1990; OLSON, 1994, 1998, 2009; WATSON, 1996, 2002). A qualidade desses intercâmbios, entre professores e alunos, influi na qualidade de oportunidades para aprender sobre a linguagem e o escrito a partir dos textos.

Apesar dos argumentos que justificam as práticas a partir de textos escritos - em particular os textos procedentes de livros de literatura infantil - nos processos de alfabetização inicial, continua vigente o debate que contrapõe tais práticas a um ensino centrado no sistema da escrita e no rápido desenvolvimento de habilidades de reconhecimento de palavras escritas (AYRA et al., 2005). Longe de fomentar-se uma integração entre esses aspectos, as práticas centradas no código continuam a afastar a leitura e o discurso acerca dos textos escritos no ensino inicial da leitura e da escrita. Esse fato é especialmente crítico porque não reconhece "quão 'letradas' são as crianças antes de se tornarem'alfabetizadas”" (TEBEROSKY, 1993, p. 47), e por isso, desconhece que as crianças têm um potencial para continuar a desenvolver com sucesso o conhecimento sobre a linguagem e os textos escritos.

No Brasil, há vários anos se desenvolvem importantes esforços governamentais para incentivar mudanças nesse aspecto; quer nas políticas curriculares, nos processos de formação continuada de professores alfabetizadores, ou nos materiais didáticos, entre outras. Em uma recente análise, Silva e Cafiero (2011) explicam que os atuais livros didáticos de alfabetização, recomendados pelo Programa Nacional do Livro Didático (PNLD), integram a perspectiva centrada no sistema da escrita com a perspectiva letrada. Segundo as autoras, tem-se atingido um importante nível de qualidade na concretização de propostas pedagógicas que garantem a leitura e a produção de textos escritos, a aprendizagem do sistema da escrita e a promoção da linguagem oral. No entanto, elas afirmam que se desconhece se as práticas de alfabetização estão realmente sendo guiadas por essas novas propostas. 
No contexto próximo do desenvolvimento do Pacto Nacional pela Alfabetização na Idade Certa, liderado pelo Ministério de Educação (MEC) (BRASIL, 2012), será de especial relevância obter dados sobre o real impacto desse conjunto de esforços, e compreender o modo pelo qual as propostas divulgadas, tanto nos processos de formação continuada como nos materiais didáticos, ajudam os professores a modificar ou melhorar suas práticas alfabetizadoras.

A pesquisa apresentada neste artigo visa apreender a compreensão e o uso, por parte de professores alfabetizadores, de um dos materiais distribuídos pelo MEC para o ensino e a aprendizagem inicial da leitura, da escrita e da oralidade. Esta pesquisa teve caráter de estudo piloto, para a qual foi solicitado a um pequeno grupo de professoras que fizesse uso de um dos exemplares do material complementar oferecido pelo MEC (BRASIL, 2011), que propõe o desenvolvimento de práticas de alfabetização a partir da leitura de livros de literatura infantil. Nesta pesquisa, o nosso objetivo foi verificar o alcance dos instrumentos de observação e de análise selecionados a fim de investigar se esse tipo de material tem potencial para influenciar as práticas de alfabetização nas salas de aula e, em caso afirmativo, de que maneira.

\section{Metodologia}

Participaram da pesquisa quatro professoras de primeiro ano de Ensino Fundamental, com turmas de 15 a 20 alunos. Dados relativos à idade, formação acadêmica, anos de experiência profissional e na área de alfabetização são apresentados na seguinte tabela (Tabela 1).

Tabela 1. Dados descritivos das professoras participantes (informações fornecidas pelas participantes)

\begin{tabular}{|c|c|c|c|c|}
\hline & $\begin{array}{l}\text { Professora } 1 \\
\text { (P1) }\end{array}$ & $\begin{array}{l}\text { Professora } 2 \\
(\mathrm{P} 2)\end{array}$ & $\begin{array}{l}\text { Professora } 3 \\
\text { (P3) }\end{array}$ & $\begin{array}{l}\text { Professora } 4 \\
\text { (P4) }\end{array}$ \\
\hline Idade & 24 & 28 & 39 & 30 \\
\hline $\begin{array}{l}\text { Anos de experiência } \\
\text { profissional docente }\end{array}$ & 8 & 7 & 17 & 8 \\
\hline $\begin{array}{l}\text { Anos de experiência em } \\
\text { alfabetização inicial }\end{array}$ & 2 & 4 & 13 & 1 \\
\hline Formação acadêmica & $\begin{array}{l}\text { Pedagoga } \\
\text { Especialista em } \\
\text { psicopedagogia } \\
\text { Curando } 3^{\circ} \text { ano } \\
\text { de Psicologia }\end{array}$ & $\begin{array}{l}\text { Matemática } \\
\text { Pedagoga } \\
\text { Pós-graduação } \\
\text { em gestão com } \\
\text { ênfase na edu- } \\
\text { cação infantil e } \\
\text { nos anos ini- } \\
\text { ciais }\end{array}$ & Pedagoga & $\begin{array}{l}\text { Pedagoga } \\
\text { Especialista em } \\
\text { psicopedagogia }\end{array}$ \\
\hline
\end{tabular}


A pesquisa foi realizada em um município distante dos grandes centros urbanos, localizado na região noroeste do Mato Grosso. 0 município tem uma população aproximada de 8.000 habitantes, dos quais um pouco menos da metade vive no núcleo urbano. Na cidade há duas escolas, uma de responsabilidade da administração estadual e a outra, a cargo do governo municipal. No total havia cinco turmas de primeiro ano, mas a pesquisa foi realizada em quatro devido à impossibilidade de participação, por motivo de licença, de uma das professoras.

\section{MATERIAIS}

Neste estudo foi utilizado um dos Materiais Complementares recentemente distribuídos pelo MEC. Trata-se de um dos Cadernos que compõem a coleção de materiais educativos denominada Trilhas, para o ensino da leitura, escrita e oralidade (BRASIL, 2011). Trilhas propõe a professores de crianças de 4 a 6 anos, um conjunto de práticas de alfabetização com especial referência aos livros de literatura infantil tentando, assim, promover a criação de espaços de cultura escrita na alfabetização inicial. A coleção é de orientação construtivista (TEBEROSKY, 2001, 2011) e está inspirada nas aproximações de aprendizagem baseadas no uso da linguagem (TOMASELLO, 1999).

Trilhas é formado por três grandes conjuntos de materiais, um centrado em jogos da linguagem, outro em textos poéticos e outro em livros narrativos. Desse último conjunto, selecionamos o Caderno de Orientações: histórias com repetição. Esse Caderno explica o que são as histórias com repetição e justifica a sua importância; descreve também uma série de livros de literatura infantil como exemplos de histórias com repetição e então apresenta oito propostas de atividades para realização em sala de aula a partir desse tipo de livros.

No Anexo 1 observa-se uma dupla página do Caderno com explicações sobre a estrutura das atividades propostas ao professor. As professoras que participaram desta pesquisa receberam este Caderno de Orientações, o livro de literatura infantil Bruxa, Bruxa venha à minha festa, de Arden Druce e Pat Ludlow, e o Caderno de Estudos correspondente ao conjunto de materiais centrados em textos narrativos.

\section{Procedimento}

De acordo com o objetivo da pesquisa, ao estudar o impacto dos materiais educativos que tentam introduzir práticas letradas nos processos de 
alfabetização e, mais especificamente, a compreensão e uso de um desses materiais, o procedimento de levantamento de dados incluiu, em primeiro lugar, uma caracterização das práticas alfabetizadoras de cada uma das professoras participantes; em segundo lugar, a entrega dos materiais educativos selecionados para a realização da pesquisa; e, posteriormente, o registro do uso dos materiais entregues para a realização de atividades na sala de aula a partir da leitura de um livro de literatura infantil.

Para caracterizar as práticas de alfabetização desenvolvidas usualmente pelas professoras registramos em vídeo: a) uma sessão de aula: solicitamos às professoras permissão para registrar "o que acontece usualmente nas aulas de alfabetização"; e b) uma sessão de leitura de um livro de literatura infantil selecionado pelas professoras. Às professoras participantes que manifestaram que liam livros na sala de aula, foi requerida permissão para registrar uma dessas sessões. Também tomamos notas sobre os materiais usados pelas professoras e alunos e sobre os comentários e explicações espontâneas das professoras.

Posteriormente entregamos o material correspondente ao Caderno de Orientações: histórias com repetição, o livro de literatura infantil Bruxa, Bruxa venha à minha festa e o Caderno de Estudos correspondente ao conjunto de propostas narrativas da coleção Trilhas. Explicamos a cada uma das professoras que se tratava de um material para alfabetização inicial que propõe atividades relacionadas à leitura de livros de literatura infantil. Mencionamos que a pesquisa consistiria em conhecer sua resposta a esse material e que isso incluiria em primeiro lugar a leitura do Caderno de Orientações com o objetivo de planejar atividades a serem realizadas com sua respectiva turma. Explicitou-se que o número de atividades a realizar era optativo, poderiam ser a totalidade das propostas (oito), ou as que ela avaliasse convenientes para a turma. Em relação ao Caderno de Estudos explicou-se que era um material de consulta optativa, no qual encontraria explicações ampliadas das propostas de atividades feitas no Caderno de Orientações.

As professoras tiveram entre 15 e 20 dias para consultar os materiais e planejar suas aulas. Durante este processo e até a finalização da pesquisa não contaram com nenhum tipo de assessoria. Finalmente, registramos em vídeo as atividades desenvolvidas por cada professora na sala de aula.

\section{ANÁLISE DOS DADOS}

Depois de caracterizar as práticas de alfabetização desenvolvidas usualmente 
pelas professoras participantes, a principal análise centrou-se no estudo das sessões de leitura de livros de literatura infantil registradas: a primeira, realizada antes da entrega do material educativo selecionado e a segunda, após a entrega do material. Assim, optamos por realizar uma análise comparativa para contrastar as práticas habituais de leitura de livros na sala de aula e as práticas realizadas seguindo as orientações dos materiais Trilhas. Os aspectos identificados para realizar a comparação foram:

- Os segmentos de atividade. A partir da proposta de Coll et al. (1995), de análise das formas de organização da atividade entre professores e alunos, foram identificados os diferentes conjuntos de ações que caracterizaram a atividade realizada por professora e alunos na sessão de leitura de livros de literatura infantil. A organização dos dados que permite essa análise visualiza a macro-organização da atividade, aspecto especialmente útil na realização de comparações e na interpretação dos dados.

- O tempo dedicado à realização dos diferentes segmentos da atividade. Contabilizou-se a duração de cada segmento identificado para visualizar e comparar o desenvolvimento das atividades.

- A fala sobre os textos. Foram identificados e categorizados os enunciados da professora com referência aos textos lidos. Nossa atenção ao discurso que se constrói na aula a partir e sobre os textos responde à hipótese letrada (OLSON; ASTINGTON, 1990), apresentada na introdução deste artigo, que atribui os efeitos positivos das práticas com livros e textos às referências e comentários textuais, isto é, ao que se diz/pensa a propósito dos textos.

Também com o objetivo de analisar a compreensão e uso das propostas do Caderno de Orientações: histórias com repetição(texto guia das professoras) organizou-se um inventário de ações que se esperava que fossem realizadas na sala de aula. O inventário reproduziu as instruções dadas pelo Caderno de Orientações às professoras para a realização das atividades na sala de aula e os exemplos de consignas a utilizar com os alunos (o que ele/a pode dizer, comentar).

\section{RESULTADOS}

Os resultados se apresentam em duas partes. A primeira expõe as observações relativas às atividades e aos materiais típicos usados pelas participantes nos processos de alfabetização inicial e caracteriza uma sessão de leitura de um livro de literatura infantil. A segunda parte apresenta os resultados relativos 
ao uso das propostas do Caderno de Orientações: histórias com repetição. Em particular, são analisadas as atividades que foram realizadas por todas as professoras participantes e se contrasta a primeira sessão de leitura de livros de literatura infantil com aquela realizada de acordo com as orientações dos materiais entregues.

CARACTERIZAÇÃo dAS PRÁtICAS de ALFABETIZAÇÃo PRÉVIAS À ENTREGA doS MATERIAIS COMPLEMENTARES

As observações realizadas nas aulas, os comentários espontâneos das professoras e a documentação obtida com a observação dos cadernos dos alunos e dos materiais didáticos usados na sala deu lugar à caracterização que se segue.

As professoras participantes utilizam métodos fônicos e silábicos na sua prática pedagógica (ver Tabela 2), sem recorrer às práticas de construção do sistema da escrita, isto é, relativas a pensar o sistema (produção e análise de diversidade de palavras escritas; análise e produção de rimas; atenção ao desenvolvimento de conhecimento gráfico e fonológico; etc.) nem às práticas próprias do desenvolvimento de conhecimentos letrados (interpretação das produções infantis não convencionais; trabalho com textos autênticos; atenção à oralidade; conexão entre práticas de leitura, escrita e oralidade, etc.).

Duas professoras declararam explicitamente que acreditam que as crianças não se alfabetizam com métodos orientados ao letramento (P2, P3). Ainda que tenham um livro didático recomendado pelo MEC, que propõe atividades baseadas em textos, as professoras assinalaram que não compreendem como a partir de um texto se pode ensinar a ler e a escrever. Por isso, usam como principal material didático uma cartilha que lhes permite ensinar o sistema de escrita de forma sistemática e ordenada.

Tabela 2. Identificação das atividades típicas de aula na área de alfabetização (registradas a partir de uma sessão de observação de duas horas)

\begin{tabular}{|c|c|c|c|c|}
\hline Atividades típicas de aula & P1 & P2 & P3 & P4 \\
\hline Cópia & $x$ & $x$ & $x$ & $x$ \\
\hline Ditado de palavras (da professora às crianças) & $x$ & $x$ & $X$ & $x$ \\
\hline $\begin{array}{l}\text { Leitura individual dos alunos com correção da } \\
\text { professora }\end{array}$ & $x$ & & $x$ & $x$ \\
\hline Leitura coletiva de silabários & & $x$ & & $x$ \\
\hline Leitura individual de silabário & & $x$ & & $x$ \\
\hline Segmentação das palavras em sílabas & & & & $x$ \\
\hline
\end{tabular}


A maioria das crianças domina o princípio alfabético; consegue terminar com rapidez as tarefas propostas (especialmente o ditado de palavras) e preenche o tempo colorindo as fichas de exercícios. As práticas estão centradas no conhecimento do sistema de escrita alfabética, sem referência aos textos. $\mathrm{Na}$ rotina diária não há leitura de livros, essa é uma atividade complementar que se realiza com uma frequência aleatória. Segundo as descrições das professoras, a atividade consiste em ler para as crianças e "fazer a interpretação", isto é, oferecer às crianças uma interpretação do significado do texto.

CARACTERIZAÇÃo DE UMA SESSÃo DE LEITURA DE LIVROS DE LITERATURA INFANTIL

As professoras responderam de formas diferentes à solicitação de mostrar o que faziam tipicamente quando liam livros de literatura infantil aos seus alunos (ver Tabela 3).

Tabela 3. Identificação dos segmentos da atividade em uma sessão de leitura de livros

\begin{tabular}{|c|c|}
\hline Professora & Segmentos da atividade \\
\hline Professora 1 & $\begin{array}{l}\text { Escolha do livro. A professora apresenta dois livros disponíveis na sala e pede aos } \\
\text { alunos que elejam. } \\
\text { Leitura em voz alta. A professora faz uma leitura contínua, com interrupções so- } \\
\text { mente para mostrar imagens aos alunos e controlar sua conduta. } \\
\text { Respostas à leitura. A professora estimula as crianças a dizer por que gostaram ou } \\
\text { não do livro. } \\
\text { Tarefa escrita. A professora pede aos alunos que escrevam no caderno três frases } \\
\text { sobre a história. }\end{array}$ \\
\hline Professora 2 & $\begin{array}{l}\text { - Apresentação do livro. A professora lê o título e o nome do autor. } \\
\text { - } \text { doitura em voz alta. A professora faz uma leitura ininterrupta, mantendo a atenção pistas não verbais (entonação). } \\
\text { - } \text { Reconto do texto. A professora começa o reconto mostrando as ilustrações e pede } \\
\text { Tarefa de desenhar. A professora pede aos alunos que desenhem os objetos que } \\
\text { aparecem no livro. }\end{array}$ \\
\hline Professora 3 & $\begin{array}{l}\text { - Apresentação do livro. Lê o título e o nome do autor, mostra a capa e pede para os } \\
\text { alunos fazerem antecipações. } \\
\text { Leitura em voz alta. A professora faz uma leitura ininterrupta, mantendo atenção } \\
\text { dos alunos com pistas não verbais (entonação) e, em algumas ocasiões, pede que } \\
\text { completem trechos do texto que se repetem. }\end{array}$ \\
\hline Professora 4 & 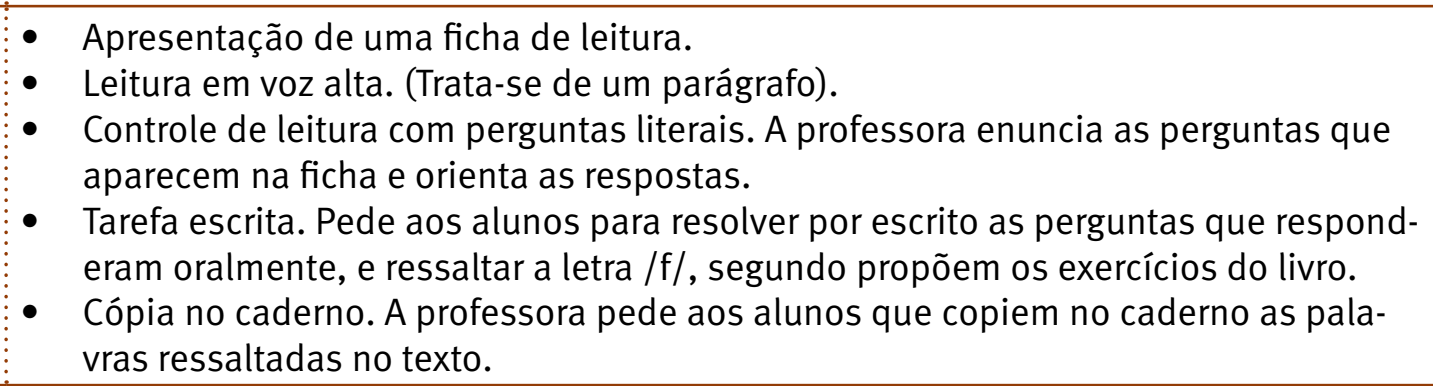 \\
\hline
\end{tabular}


A Professora 1 começou sua aula pedindo aos alunos que escolhessem o livro de leitura entre duas opções: Bambi ou Branca de Neve. Ela garantiu que os alunos estivessem próximos do livro e que conseguissem visualizar as ilustrações. Durante a leitura, os comentários sobre o livro se restringiram à denominação de aspectos da imagem e depois da leitura, se orientaram a avaliar a história em termos globais.

A Professora 2 começou a aula apresentando o livro, mostrando a capa, lendo o título e o nome do autor. O livro selecionado pela professora foi Dentro da casa tem (uma história encadeada, apresentada em um livro com predomínio da imagem). A professora fez uma leitura contínua do texto, garantindo que os alunos observassem a página dupla e usando diversos recursos não linguísticos para manter a atenção. Concluída a primeira leitura do texto, a professora fez mais duas releituras, com uma evidente preocupação por enunciar e expor repetidas vezes aos alunos o itinerário relatado no texto. Segundo o registro do tempo, fez a leitura em voz alta e duas releituras em um período de 6 minutos. Contudo, essa exposição repetida ao texto não esteve orientada a estimular a produção oral nem a produção escrita por parte dos alunos. A memória criada sobre o livro serviu de contexto para uma tarefa de produção individual focada em “desenhar o que está na história e escrever o nome”.

A Professora 3 começou sua sessão apresentando o livro (mostrando a capa, lendo o título) e formulando perguntas para que os alunos fizessem antecipações sobre o seu possível conteúdo. Porém, além da pergunta desencadeante inicial - "vocês acham que é sobre quê?" -, não formulou outro tipo de questões sobre as respostas infantis, que se converteram em um circunlóquio ao redor de uma mesma ideia (a primeira que foi proposta). $O$ livro lido foi $A$ incrível poção mágica. A professora fez uma leitura contínua, interrompida em escassas ocasiões para pedir aos alunos que repetissem ou completassem trechos de caráter repetitivo (fórmulas). Após a leitura, a professora reapresentou as ilustrações do texto e comentou um aspecto marcante: a presença de figuras geométricas, fato que foi aproveitado para fazer referência a um trabalho feito em classe sobre tais figuras. A atividade terminou com a solicitação feita pela professora para que os alunos avaliassem globalmente a leitura do livro: "gostaram da história?".

A Professora 4, diferentemente das demais, elegeu para a sessão de leitura não um livro, mas sim um texto curto (composto por 44 palavras) de uma ficha de leitura. A professora apresentou a ficha, fazendo referência às atividades de leitura e resolução de perguntas que fariam após a leitura. Desenvolveu as atividades: leitura; perguntas literais e extração de palavras com a letra /f/. 
A Tabela 4 classifica as atividades realizadas por professoras e alunos seguindo um critério temporal - antes, durante e depois da leitura - e comparando o trabalho das quatro turmas. Quanto às atividades realizadas antes da leitura, destaca-se que somente uma das três professoras convidou os alunos a formular antecipações sobre o conteúdo do texto, a partir da observação da capa e da leitura do título do livro. As outras professoras referiram-se apenas ao título do livro e ao nome do autor. Durante a leitura, somente as professoras 1 e 3 realizaram comentários, contudo, foram comentários de caráter referencial. A professora 3 foi a única que, durante a leitura, convidou os alunos a participarem repetindo e completando trechos do texto.

A Figura 1 compara os segmentos da atividade colocando em relevo o tempo dedicado a cada uma. Em todos os casos, chama a atenção o escasso tempo dedicado à introdução da atividade e à leitura. Duas das professoras (P2 e P4) dedicaram a esta atividade menos de $6 \%$ do tempo da sessão, outra dedicou $18 \%$ (P1) e no caso da P3 realizou a atividade em 17 minutos e a deu por concluída. A maior quantidade de ações e de tempo foi empregada nas atividades após a leitura. Em dois casos, uma parte da sessão se dedicou à avaliação geral das crianças sobre o livro (P1 e P3): as professoras estimularam as crianças a dizer por que tinham gostado ou não do livro. 0 último segmento foi o mais extenso. As professoras usaram a quase totalidade da sessão ( $P$ 1: 82\%, P2: 93\% e P4: 95\%) com o desenvolvimento, por parte das crianças, de tarefas de produção individual (frases escritas, desenhos).

Tabela 4. Comparação entre as professoras dos segmentos da atividade realizadas antes, durante e depois da leitura

\begin{tabular}{|c|c|c|c|}
\hline Professora & Antes & Durante & Depois \\
\hline Professora 1 & Escolha do livro & $\begin{array}{l}\text { Detêm a leitura } \\
\text { para mostrar as } \\
\text { ilustrações. } \\
\text { Comentários } \\
\text { referenciais (aqui } \\
\text { é, essa é). }\end{array}$ & $\begin{array}{l}\text { Avaliação global } \\
\text { da leitura (Gosta- } \\
\text { ram? A parte que } \\
\text { mais gostaram?) } \\
\text { Escrita individual } \\
\text { de } 3 \text { frases sobre } \\
\text { a história. }\end{array}$ \\
\hline Professora 2 & $\begin{array}{l}\text { Apresentação do } \\
\text { livro. }\end{array}$ & & $\begin{array}{l}\text { Reconto do texto } \\
\text { repassando as } \\
\text { ilustrações. } \\
\text { Produção indi- } \\
\text { vidual de desen- } \\
\text { hos. }\end{array}$ \\
\hline
\end{tabular}




\begin{tabular}{|c|c|c|c|}
\hline Professora & Antes & Durante & Depois \\
\hline Professora 3 & $\begin{array}{l}\text { Apresentação } \\
\text { do livro e formu- } \\
\text { lação de anteci- } \\
\text { pações. }\end{array}$ & $\begin{array}{l}\text { Detêm a leitura } \\
\text { para mostrar as } \\
\text { ilustrações. } \\
\text { Perguntas e } \\
\text { comentários } \\
\text { referenciais (essa } \\
\text { aqui quem é). } \\
\text { Completar tre- } \\
\text { chos repetitivos } \\
\text { do texto. }\end{array}$ & $\begin{array}{l}\text { Reapresentação } \\
\text { das ilustrações } \\
\text { do livro. }\end{array}$ \\
\hline Professora 4 & $\begin{array}{l}\text { Apresentação da } \\
\text { ficha de leitura. }\end{array}$ & & $\begin{array}{l}\text { Controle de } \\
\text { leitura através de } \\
\text { perguntas descri- } \\
\text { tivas e literais. } \\
\text { Resolução indi- } \\
\text { vidual da ficha } \\
\text { de leitura. }\end{array}$ \\
\hline
\end{tabular}

TRABAlHo A PARTIR Do CADERNO DE ORIENTAÇÕES:HISTÓRIAS COM REPETIÇÃO

A partir da leitura do Caderno de Orientações: histórias com repetição e da consulta optativa do Caderno de Estudos: trilhas para ler e escrever textos, as professoras planejaram atividades relacionadas com a leitura do livro de literatura infantil Bruxa, Bruxa, venha à minha festa. 0 Caderno de Orientações propõe oito atividades possíveis de serem realizadas (ver Tabela 5). Duas das professoras (P1 e P4) decidiram por fazer somente as atividades 1 e 2, que correspondem à apresentação e leitura do livro, essas atividades foram realizadas em uma sessão de aula. A Professora 2 decidiu realizar a maioria das atividades propostas e as desenvolveu em um período de aulas (uma jornada escolar). Finalmente, a Professora 3 decidiu fazer todas as atividades propostas e as distribuiu em cinco sessões diferentes, cada uma realizada em um dia diferente. 
Figura 1. Comparação de segmentos da atividade de uma sessão de leitura de um livro de literatura infantil

\begin{tabular}{|c|c|c|c|c|c|}
\hline & Minuto & P1 & P2 & P3 & P4 \\
\hline $11 \%$ & $\begin{array}{l}0 \\
10\end{array}$ & $\begin{array}{l}\text { Escolha do livro (1') } \\
\text { Leitura em voz alta } \\
\left(10^{\prime}\right) \\
\text { Comentário (5') }\end{array}$ & $\begin{array}{l}\text { Apresentação } \\
\text { do livro (15'”) } \\
\text { Leitura em } \\
\text { voz alta (2') } \\
\text { Reconto do } \\
\text { texto (3'30”) }\end{array}$ & & $\begin{array}{l}\text { Explicação } \\
\text { da atividade } \\
(10 \text { ') Leitura } \\
\text { em voz alta } \\
\text { (22')Controle } \\
\text { de leitura (3') }\end{array}$ \\
\hline $33 \%$ & 30 & $\begin{array}{l}\text { Tarefa escrita } \\
\text { individual }\end{array}$ & $\begin{array}{l}\text { Tarefa de } \\
\text { desenhar indi- } \\
\text { vidualmente }\end{array}$ & & $\begin{array}{l}\text { Tarefa escrita } \\
\text { individual }\end{array}$ \\
\hline $\begin{array}{l}44 \% \\
55 \%\end{array}$ & 50 & & & $\begin{array}{l}\text { Apresentação } \\
\text { do livro (1'45”) } \\
\text { Leitura em } \\
\text { voz alta (11') } \\
\text { Reapresentação } \\
\text { de ilustrações e } \\
\text { comentário (4') }\end{array}$ & \\
\hline $66 \%$ & 60 & & & & \\
\hline $77 \%$ & 70 & & & & \\
\hline $88 \%$ & 80 & & & & \\
\hline $100 \%$ & 90 & & & & \\
\hline
\end{tabular}


Tabela 5. Atividades escolhidas pelas professoras para desenvolver na sala de aula

\begin{tabular}{lllll} 
Atividades & $\mathrm{P} 1$ & $\mathrm{P} 2$ & $\mathrm{P} 3$ & $\mathrm{P} 4$ \\
Conhecer o livro "por fora" e "por dentro" & $\mathrm{X}$ & $\mathrm{X}$ & $\mathrm{X}$ & $\mathrm{X}$ \\
\hline Ler trechos da história & $\mathrm{X}$ & $\mathrm{X}$ & $\mathrm{X}$ & $\mathrm{X}$ \\
\hline Localizar nomes e ditar uma lista & & $\mathrm{X}$ & $\mathrm{X}$ & \\
\hline Desenhar os convidados que aparecem no livro & & $\mathrm{X}$ & $\mathrm{X}$ & \\
\hline Relacionar ilustrações e diálogos & & $\mathrm{X}$ & $\mathrm{X}$ & \\
\hline Escrever nomes com letras móveis & & $\mathrm{X}$ & $\mathrm{X}$ & $\vdots$ \\
\hline Escrever em texto com lacunas & & & $\mathrm{X}$ & \\
\hline Ordenar os diálogos da história & & & $\mathrm{X}$ & \\
\hline
\end{tabular}

A análise aqui proposta centrou-se nos resultados da comparação das atividades 1 e 2 realizadas por todas as professoras. Essas atividades correspondem à apresentação do livro e à sua leitura.

\section{APRESENTAÇÃO E LEITURA EM VOZ ALTA SEGUINDO AS ORIENTAÇÕES OFERECIDAS} PELO MATERIAL TRILHAS

A Tabela 6 mostra as ações realizadas pelas professoras antes, durante e depois da leitura do livro. Entre as semelhanças, se observa a realização de uma leitura compartilhada do texto e a realização de comentários interpretativos. Ainda que todas fizessem uma apresentação do livro como suporte do texto, que incluiu mostrar a capa, referir o título e nome do autor e ilustrador, somente as professoras 1 e 3 usaram essa apresentação para levar os alunos a formularem antecipações sobre o texto. De forma similar, aconteceu com a atividade de apresentar as ilustrações do livro aos alunos antes da leitura. Ainda que duas professoras (P2 e P3) o fizessem, somente uma (P3) usou a atividade para suscitar comentários por parte dos alunos.

Em relação ao uso do tempo (Figura 2), as professoras 1 e 3 realizaram as atividades em 30 e 38 minutos, respectivamente. A P1 dedicou a maior parte do tempo à leitura compartilhada do livro e a P3 à apresentação e comentário das ilustrações antes da leitura. As professoras 2 e 4, diferentemente das anteriores, além de apresentarem e lerem o livro, desenvolveram outras das atividades propostas. Em relação ao uso do tempo, observamos que nos dois casos a atividade de leitura ocupou o menor tempo da sessão (18\% e 14\% respectivamente). A maior parte do tempo se dedicou ao desenvolvimento de tarefas individuais (colorir desenhos e fazer uma lista, respectivamente).

A análise realizada com o inventário de ações esperadas para as atividades 1 
e 2 (ver Tabela 7) - que reproduz as orientações oferecidas pelo material de Trilhas - mostra que as professoras seguiram, em parte, o roteiro dado. Ainda que contrastássemos as ações em inventários separados (seguindo a divisão apresentada no Caderno de Orientações), esses correspondem, em todos os casos, às atividades realizadas em uma única sessão e de forma integrada.

Em resumo, a Tabela 7 mostra que todas as professoras garantiram a proximidade das crianças com o livro, realizaram comentários dirigidos a apresentar o livro "por fora" - como suporte do texto-, apontaram o local onde estavam escritos os nomes dos autores, estimularam comentários a partir das ilustrações do livro, e propuseram e realizaram uma leitura compartilhada do livro. Segundo esse registro, as diferenças entre as professoras se relacionaram basicamente com:

- A adesão às expressões propostas pelas orientações como possíveis consignas. Somente as professoras 1 e 3 incorporaram a linguagem proposta para estimular a formulação de antecipações por parte das crianças.

- O acompanhamento da intencionalidade explicitada para os segmentos de atividade nas orientações. As professoras 1 e 3 conseguiram vincular as atividades de apresentação do livro com o objetivo apresentado no caderno de "Relacionar informações da capa e da contracapa do livro e fazer antecipações sobre a história".

- A majoritária incorporação das orientações relativas à atividade Ler trechos da história feita pela professora 3. Só ela realizou ações orientadas a promover a exploração das ilustrações com o objetivo de antecipar o texto. 


\begin{tabular}{|c|c|c|c|}
\hline Prof. & Antes & Durante & Depois \\
\hline Prof. 1 & $\begin{array}{l}\text { Organização do espaço } \\
\text { e das crianças. } \\
\text { Apresentação do } \\
\text { livro e formulação de } \\
\text { antecipações. }\end{array}$ & $\begin{array}{l}\text { Introdução de marcos } \\
\text { para o discurso direto } \\
\text { (diálogos). } \\
\text { Explicitação de } \\
\text { informações implícitas. } \\
\text { Formulação de perguntas } \\
\text { antecipatórias. } \\
\text { Leitura compartilhada de } \\
\text { trechos. } \\
\text { Comentário e } \\
\text { interpretações dos } \\
\text { alunos. }\end{array}$ & \\
\hline Prof. 2 & $\begin{array}{l}\text { Organização do espaço } \\
\text { e das crianças. } \\
\text { Apresentação do } \\
\text { livro e explicitação de } \\
\text { informações implícitas. }\end{array}$ & $\begin{array}{l}\text { Leitura } \\
\text { compartilhada } \\
\text { de trechos. }\end{array}$ & $\begin{array}{l}\text { Reconto do texto } \\
\text { repassando as } \\
\text { ilustrações. } \\
\text { Explicitação da } \\
\text { interpretação do texto, } \\
\text { feita pela professora. } \\
\text { Colorir desenhos. } \\
\text { Composição do nome } \\
\text { das personagens com } \\
\text { letras móveis. }\end{array}$ \\
\hline Prof. 3 & $\begin{array}{l}\text { Organização do espaço } \\
\text { e das crianças. } \\
\text { Apresentação do } \\
\text { livro e formulação de } \\
\text { antecipações. } \\
\text { Observação e } \\
\text { comentário das } \\
\text { ilustrações do livro. }\end{array}$ & $\begin{array}{l}\text { Leitura compartilhada de } \\
\text { trechos. } \\
\text { Introdução de marcos } \\
\text { para o discurso direto } \\
\text { (diálogos). } \\
\text { Designação de atos } \\
\text { enunciativos. }\end{array}$ & $\begin{array}{l}\text { Explicitação da } \\
\text { interpretação do texto, } \\
\text { feita pela professora. }\end{array}$ \\
\hline Prof. 4 & Apresentação do livro. & Leitura em voz alta. & $\begin{array}{l}\text { Leitura em voz alta. } \\
\text { Explicitação da } \\
\text { interpretação do texto, } \\
\text { feita pela professora. } \\
\text { Releitura compartilhada } \\
\text { (os alunos completam } \\
\text { trechos do texto). } \\
\text { Reapresentação das } \\
\text { ilustrações do livro. }\end{array}$ \\
\hline
\end{tabular}


Figura 2. Comparação de SEgmentos de ATIVIDAde de UMA SESSÃo DE LEITURA DE UM LIVRO DE LITERATURA INFANTIL

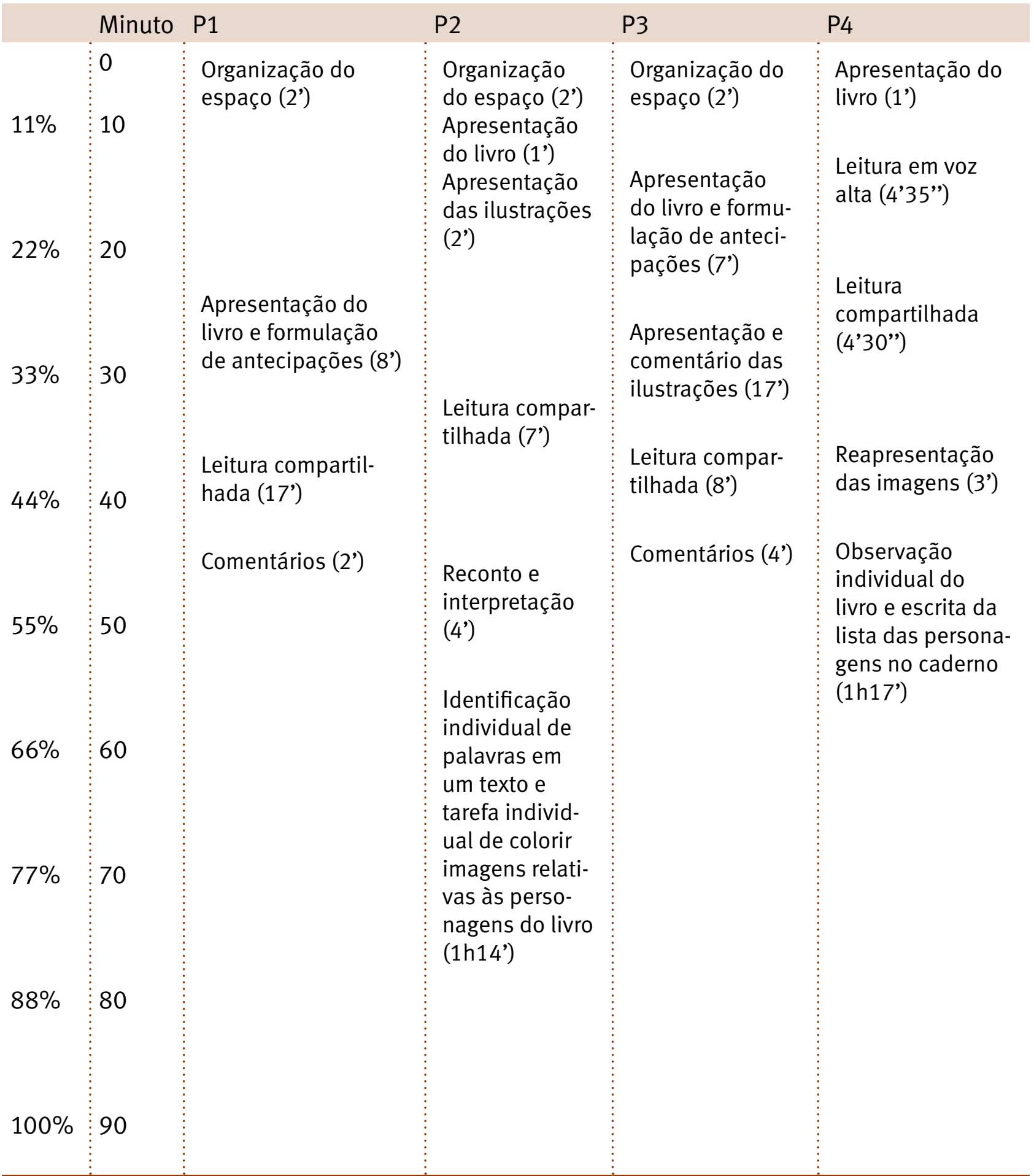


Tabela 7. O uso do Caderno de Orientações para as atividades de apresentação e leitura do livro em voz alta (inventário de ações esperadas)

\begin{tabular}{|c|c|c|c|c|}
\hline ATIVIDADE 1. CONHECER O LIVRO “POR FORA” E “POR DENTRO” & P1 & P2 & P3 & $\mathrm{P} 4$ \\
\hline $\begin{array}{l}\text { - Organização do espaço e das crianças. É importante garantir que todas vejam o } \\
\text { livro. }\end{array}$ & $\mathrm{X}$ & $x$ & $x$ & $X$ \\
\hline - Conversa apresentando o livro “por fora”. & $X$ & $\mathrm{X}$ & $\mathrm{X}$ & $X$ \\
\hline \multicolumn{5}{|l|}{ Hoje vamos conhecer um novo livro. } \\
\hline \multicolumn{5}{|l|}{$\begin{array}{l}\text { Antes de ler a história, vamos prestar atenção na capa e contracapa do } \\
\text { livro. }\end{array}$} \\
\hline Vamos primeiro ver a capa. & & & $\mathrm{X}$ & \\
\hline O que será que ela nos mostra? & $\mathrm{X}$ & & $\mathrm{X}$ & \\
\hline $\begin{array}{l}\text { - Conversa sobre a capa partindo das observações dos alunos e leitura do título: } \\
\text { "Ah! Então vocês acham que essa história fala sobre uma bruxa? Por quê? } \\
\text { Então me digam, vocês acham que o título dessa história também tem } \\
\text { "bruxa'?" }\end{array}$ & $\mathrm{X}$ & & $\mathrm{X}$ & \\
\hline $\begin{array}{l}\text { o Relacionar informações da capa e da contracapa do livro e fazer } \\
\text { antecipações sobre a história. }\end{array}$ & $x$ & & $\mathrm{X}$ & \\
\hline - Apontar o local onde está escrito o nome da autora e ler para as crianças. & $\mathrm{X}$ & $\mathrm{X}$ & $\mathrm{X}$ & $\mathrm{X}$ \\
\hline $\begin{array}{l}\text { o Perguntar a elas de quem é esse nome, dizendo, por exemplo: “Aqui } \\
\text { está escrito ‘Arden Druce'. De quem será esse nome?”. }\end{array}$ & $x$ & & & \\
\hline $\begin{array}{l}\text { Mostrar a capa e a contracapa, abrindo o livro ao meio, e pedir que } \\
\text { observem que a ilustração da capa ocupa as duas páginas centrais. }\end{array}$ & $x$ & & $\mathrm{X}$ & \\
\hline $\begin{array}{l}\text { - Estimular a formulação de perguntas, hipóteses a partir das ilustrações e a } \\
\text { busca de respostas a partir da leitura do livro. }\end{array}$ & $x$ & $x$ & $\mathrm{X}$ & \\
\hline $\begin{array}{l}\text { o É interessante não confirmar nem negar as hipóteses das crianças. } \\
\text { CS: “Será que é mesmo um monstro? Quando fizermos a leitura, } \\
\text { poderemos confirmar”. }\end{array}$ & $x$ & & $\mathrm{X}$ & \\
\hline $\begin{array}{l}\text { - Ler o primeiro parágrafo da contracapa do livro, destacando as perguntas que } \\
\text { deixarão as crianças curiosas para desvendar o fim da história. }\end{array}$ & & & $\mathrm{X}$ & \\
\hline \multicolumn{5}{|l|}{ o Escutar a história de forma ativa. } \\
\hline $\begin{array}{l}\text { - Realizar a leitura da história em voz alta para as crianças com o livro voltado } \\
\text { para elas, para que vejam as ilustrações enquanto escutam a história. }\end{array}$ & $x$ & $x$ & $x$ & $x$ \\
\hline $\begin{array}{l}\text { - Atividade adicional (o que mais é possível fazer): Entregar o livro nas mãos } \\
\text { das crianças (indo de uma em uma) e sugerir que observem os detalhes das } \\
\text { ilustrações, aproximando e distanciando os olhos do livro para que observem o } \\
\text { que muda. }\end{array}$ & & & $x$ & $x$ \\
\hline $\begin{array}{l}\text { - Atividade adicional casa (o que é possível fazer em casa). Sugerir que as crian- } \\
\text { ças contem aos pais que aprenderam uma nova história e comentem sobre as } \\
\text { ilustrações do livro. }\end{array}$ & & & & \\
\hline
\end{tabular}


- Organização do espaço e das crianças. Organizar as crianças sentadas em roda, de forma que todas possam se ver e estejam próximas do livro, que estará nas mãos do professor.

- Perguntar às crianças se elas notaram que, no livro, alguns convidados da festa aparecem na ilustração antes do convite (exemplo: na página da Coruja, aparece a Árvore, que é a convidada seguinte).

- Passar o livro para as crianças olharem ou ir mostrando de forma que percebam qual convidado da página seguinte já está presente na página anterior. Você pode dizer: "Será que conseguimos saber, só olhando para as ilustrações, qual será o próximo convidado?”

o Observar atentamente as ilustrações e antecipar o texto.

- Chamar a atenção das crianças para a localização do texto em cada uma das páginas: "Vocês notaram que em todas as páginas tem um texto, em algumas o texto está no canto de cima, e em outras no canto de baixo? Só na última página é que tem dois textos, um em cima e outro embaixo".

- Anunciar que farão uma leitura da qual todos irão participar juntos. Explicar que você começará lendo as duas primeiras páginas e pedirá que as crianças falem o texto da página seguinte. Seguir a leitura alternando com a participação das crianças: “A partir de agora vou ler uma página e gostaria que vocês lessem o que está escrito na página seguinte".

o Ler partes da história recuperando o texto de memória e observando $\begin{array}{lllllll}X & X & X & X\end{array}$ as ilustrações.

- Possíveis adaptações. Caso o desafio proposto nessa atividade se mostre muito difícil para algumas crianças, você pode propor que acompanhem a leitura realizada por você e deixem para ler em voz alta só as partes que se repetem: "Por favor, venha à minha festa"; "Obrigado, irei, sim, se você convidar a...".

\section{COMPARAÇÃO DA ATIVIDADE DE LEITURA DE LIVROS DE LITERATURA INFANTIL}

O uso do inventário de ações esperadas para atividade de leitura do livro, com o objetivo de descrever a atividade de leitura realizada pelas professoras antes de receber o Caderno de Orientações, mostra a ausência da maioria das propostas (ver Tabela 8). 
Tabela 8. Inventário de ações esperadas para analisar a atividade de leitura feita antes da entrega do material

\section{ATIVIDADE 1. CONHECER O LIVRO “POR FORA" E "POR DENTRO”}

- Organização do espaço e das crianças. É importante garantir que todas vejam o $\vdots X \vdots X \vdots X$ livro.

- Conversa apresentando o livro "por fora".

Hoje vamos conhecer um novo livro.

Antes de ler a história, vamos prestar atenção na capa e contracapa do livro.

Vamos primeiro ver a capa.

O que será que ela nos mostra?

- Conversa sobre a capa partindo das observações dos alunos e leitura do título:

o Relacionar informações da capa e da contracapa do livro e fazer antecipações sobre a história.

- Apontar o local onde está escrito o nome da autora e ler para as crianças.

o Perguntar a elas de quem é esse nome.

- Mostrar a capa e a contracapa, abrindo o livro ao meio, e pedir que observem que a ilustração da capa ocupa as duas páginas centrais.

- Estimular a formulação de perguntas, hipóteses a partir das ilustrações e a busca de respostas a partir da leitura do livro.

- Ler o primeiro parágrafo da contracapa do livro, destacando as perguntas que deixarão as crianças curiosas para desvendar o fim da história.

o Escutar a história de forma ativa.

- Realizar a leitura da história em voz alta para as crianças com o livro voltado para elas, para que vejam as ilustrações enquanto escutam a história.

- Atividade adicional (o que mais é possível fazer): Entregar o livro nas mãos das crianças (indo de uma em uma) e sugerir que observem os detalhes das ilustrações, aproximando e distanciando os olhos do livro para que observem o que muda.

- Atividade adicional casa (o que é possível fazer em casa). Sugerir que as crianças contem aos pais que aprenderam uma nova história e comentem sobre as ilustrações do livro.

0 contraste entre as Tabelas 7 e 8 põe em evidência, por um lado, a novidade que as propostas do Caderno de Orientações representaram para as professoras e, por outro, as mudanças mais notáveis: o recurso às informações da capa e contracapa para formular antecipações (P1 e P3) e o estímulo para que as crianças participassem do ato de leitura lendo palavras, completando trechos e expressando suas respostas às ilustrações do texto (P1, P2, P3 e P4).

\section{COMPARAÇÃO DA ATIVIDADE DISCURSIVA: A ANÁLISE DA FALA SOBRE OS TEXTOS}

A análise seguinte refere-se à identificação e comparação das características da atividade discursiva que teve lugar durante e após a atividade de leitura do livro. Selecionaram-se os enunciados da professora que referiam ou comentavam o 
texto. Isto é, aqueles cuja predicação remetia ao lido. Desta forma, excluíram-se os enunciados dirigidos à gestão e ao controle da atividade.

0 estudo dos enunciados selecionados pretendeu caracterizar a fala sobre 0 texto lido, o tipo e função das referências feitas. As categorias identificadas para a análise são definidas no Quadro 1 . Na continuação relata-se a comparação, realizada de acordo com esta codificação, da fala de cada uma das professoras, comparando a primeira leitura (identificada no texto como Leitura A) coma segunda leitura, realizada seguindo as orientações do material entregue (identificada como Leitura B).

\section{Quadro 1. Definição de categorias da análise para o estudo da fala sobre textos}

\section{COMENTÁRIOS REFERENCIAIS}

Integram essa categoria os enunciados da professora produzidos para indicar aspectos observáveis no livro, em geral, para denominar aspectos presentes nas ilustrações.

Paráfrase do texto

Os enunciados da professora (perguntas ou afirmações) formulados com a intencionalidade de repetir ou recontar parafraseando o texto lido.

\section{Comentários metadiscursivos}

Os enunciados (afirmações ou perguntas) que definem ou classificam os atos de fala (de leitura) no texto.

\section{Comentários conjecturais}

Os enunciados (perguntas ou afirmações) formulados para provocar conjecturas ou o ato de conjecturar, supor.

\section{Comentários interpretativos}

Os enunciados que explicitam compreensões ou deduções feitas sobre o texto lido.

\section{Comentários intertextuais}

Os enunciados que põem em relação manifesta o texto lido com outros textos.

\section{PROFESSORA 1}

Os comentários realizados pela professora durante a Leitura A tiveram um caráter referencial, foram feitos para assinalar, na ilustração, aspectos mencionados do texto. Em quase todos os comentários categorizados (10 de 11), a professora recorreu ao uso de uma linguagem demonstrativa: esse, aqui. Em apenas um comentário incluiu uma citação do texto, também com a intenção de assinalar algum aspecto da ilustração (ver exemplos na Tabela 10). Após a leitura, a professora não realizou comentários sobre o livro; sua atividade discursiva nesse segmento se dedicou a indagar sobre a avaliação geral dos alunos sobre 
a história: gostaram da historinha? Que foi o que mais gostaram?

Durante a Leitura B, os comentários da professora se diversificaram. Os mais numerosos foram os conjecturais, perguntas e afirmações introduzidas pela professora para questionar o texto e formular suposições. Também houve referências aos atos enunciativos que aparecem no texto: convites e respostas, codificados como comentários metadiscursivos. E alguns enunciados explicitaram a conexão do texto com um anterior, o conto do Chapeuzinho Vermelho (comentários intertextuais). Após a leitura, a professora fez uns poucos comentários, sendo um de caráter referencial e dois de caráter conjectural.

Tabela 10. Exemplos da análise da fala sobre textos. Professora 1.

\section{PROFESSORA 1}

Leitura A. Bambi

Leitura B. Bruxa, Bruxa, venha à minha festa.

Durante a leitura em voz alta

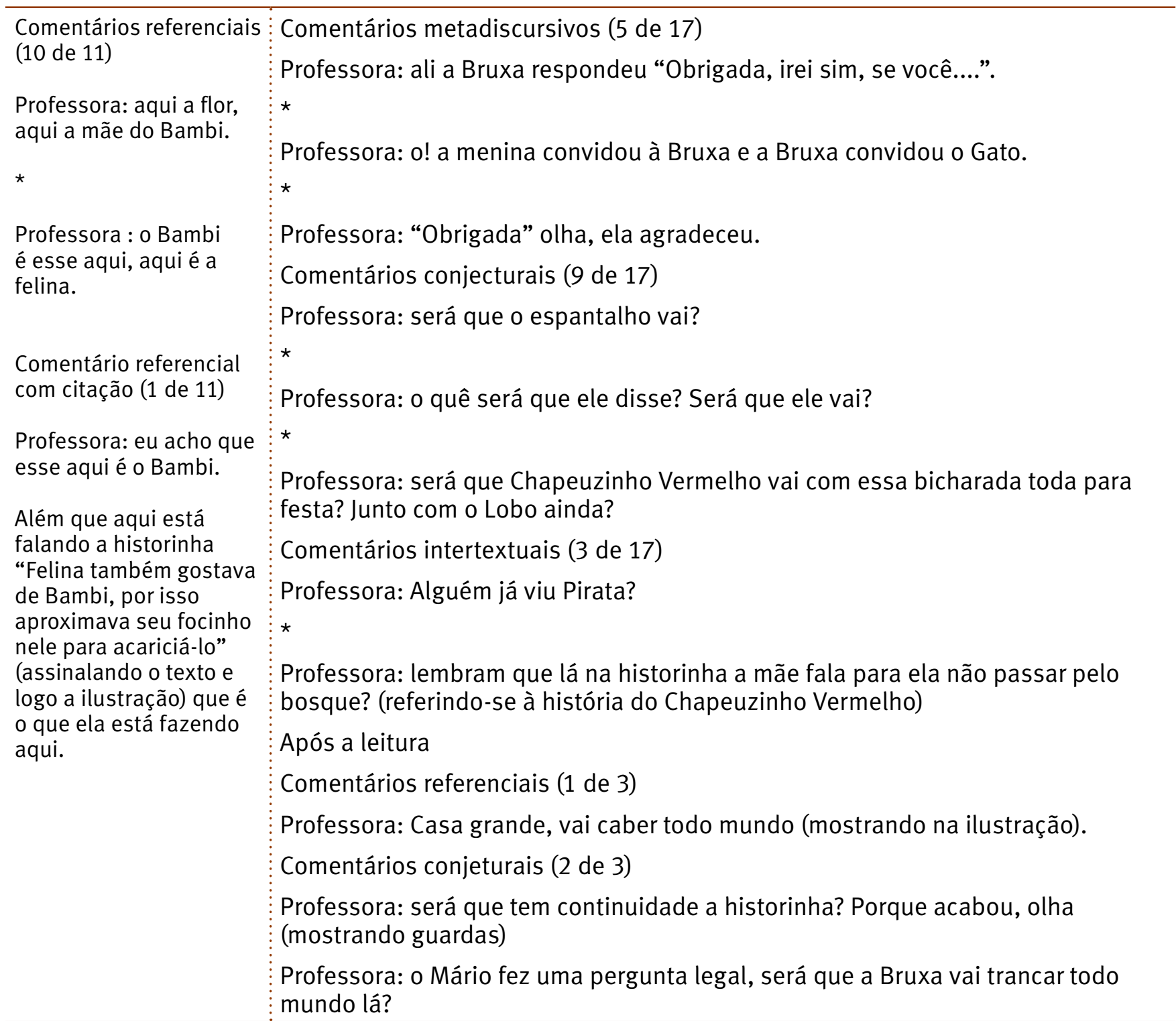


Durante a Leitura A, não se produziram enunciados metatextuais. Após a leitura, seus comentários sobre o texto foram majoritariamente paráfrases do texto, perguntas e afirmações que retomavam, repetiam ou levavam a parafrasear o texto lido. Também houve um comentário referencial. Quanto à Leitura $\mathrm{B}$, durante a leitura a professora denominou os enunciados lidos (comentários metadiscursivos) e formulou conjecturas (comentários conjecturais). Após a leitura, realizou diversos tipos de referências ao texto lido: comentários metadiscursivos; comentário sobre a estrutura do texto; o seu caráter circular e encadeado; referências intertextuais; comentários referenciais e interpretativos (ver Tabela 11). 
Tabela 11. Exemplos da análise da fala sobre textos. Professora 2.

\section{PROFESSORA 2}

Leitura A. Dentro da casa tem. Leitura B. Bruxa, Bruxa, venha à minha festa.

Durante a leitura em voz alta

Após a leitura

Paráfrases do texto (12 de 13)

Professora: o livro diz o que lá na casa tinha uma sala, na sala tem um armário, no armário tinha o que? 0 cesto, no cesto tinha o que? Uma caixa vermelha, na caixa vermelha tinha o que?

Aluno: um vidro (coro).

Professora: dentro do vidro tinha o que?

Aluno: a pulga! (coro).

*

Professora: ela pulou fora do vidro, fora da caixa, fora do cesto, da sala.

Comentários metadiscursivos

Professora: O Gato responde Obrigado, irei sim, se você convidar o (virando a página) Espantalho.

\section{*}

Professora: ela (a árvore) agradece primeiro, obrigado, irei si, só se você convidar o Duende.

Comentário conjectural (1 de

Professora: será que as crianças vão?

Após a leitura

omentários metadiscursivos (4 de 18)

Professora: Ela começou convidando quem?

*

Professora: E as criancinhas mandaram convidar quem?

Comentário sobre a estrutura do texto (2 de 18)

Sobre o caráter circular (1)

Professora: aí a historinha volta aqui de novo, no começo (manipulando o livro, da última parte ao começo e recitando) Bruxa, Bruxa, por favor, venha à minha festa. Obrigado, irei sim, só se você convidar o Gato. E aí vai voltar no começo a historinha de novo. No fim volta ao começo.

Após a leitura

Sobre o caráter encadeado (1)

Professora: a menininha, acho que estava pensando, pensando, e falou assim: quem que eu vou convidar para minha festa, vou convidar uma Bruxa. Aí ela convidou a Bruxa, a Bruxa pediu para convidar o Gato, (passando as páginas), o Gato pediu para convidar o Espantalho, o Espantalho pediu para convidar a Coruja, a Coruja pediu para convidar a Árvore, porquê? Ela fica em cima da árvore, então tinha que levar a árvore também. A Árvore pediu para convidar o Duende... (continua)

Comentário intertextual (2 de 18)

Professora: tem a intenção de comer a vovozinha, né? (não cede a palavra ao aluno).

Comentário referencial (5 de 18)

Professora: a festa vai ser aqui, muito bem. E aí as criançinhas tão vestido de Chapeuzinho, vestido de Lobo, de Cobra, Tubarão, Pirata. Então deveria criar uma festa a fantasia, né?

Comentário interpretativo ( 4 de 18)

Professora: a festa vai ser aqui, muito bem. E aí as criançinhas tão vestidas de Chapeuzinho, vestidas de Lobo, de Cobra, Tubarão, Pirata. Então deveria criar uma festa à fantasia, né?

*

Professora: E quem está indo na festa, os animais ou as criancinhas? 
Durante a primeira leitura, os comentários da professora centraram-se na paráfrase do texto lido e em denominar aspectos nas ilustrações do livro. Após a leitura, continuaram as paráfrases. Durante a Leitura B, a professora denominou os atos enunciativos lidos e estimulou a paráfrase do texto. Após a leitura, a professora centrou-se em pôr em evidência o caráter circular e encadeado do texto (comentários sobre a estrutura do texto).

Tabela 12. Exemplos da análise da fala sobre textos. Professora 3.

\section{PROFESSORA 3}

Leitura A. A incrível poção Leitura B. Bruxa, Bruxa, venha à minha festa. mágica.

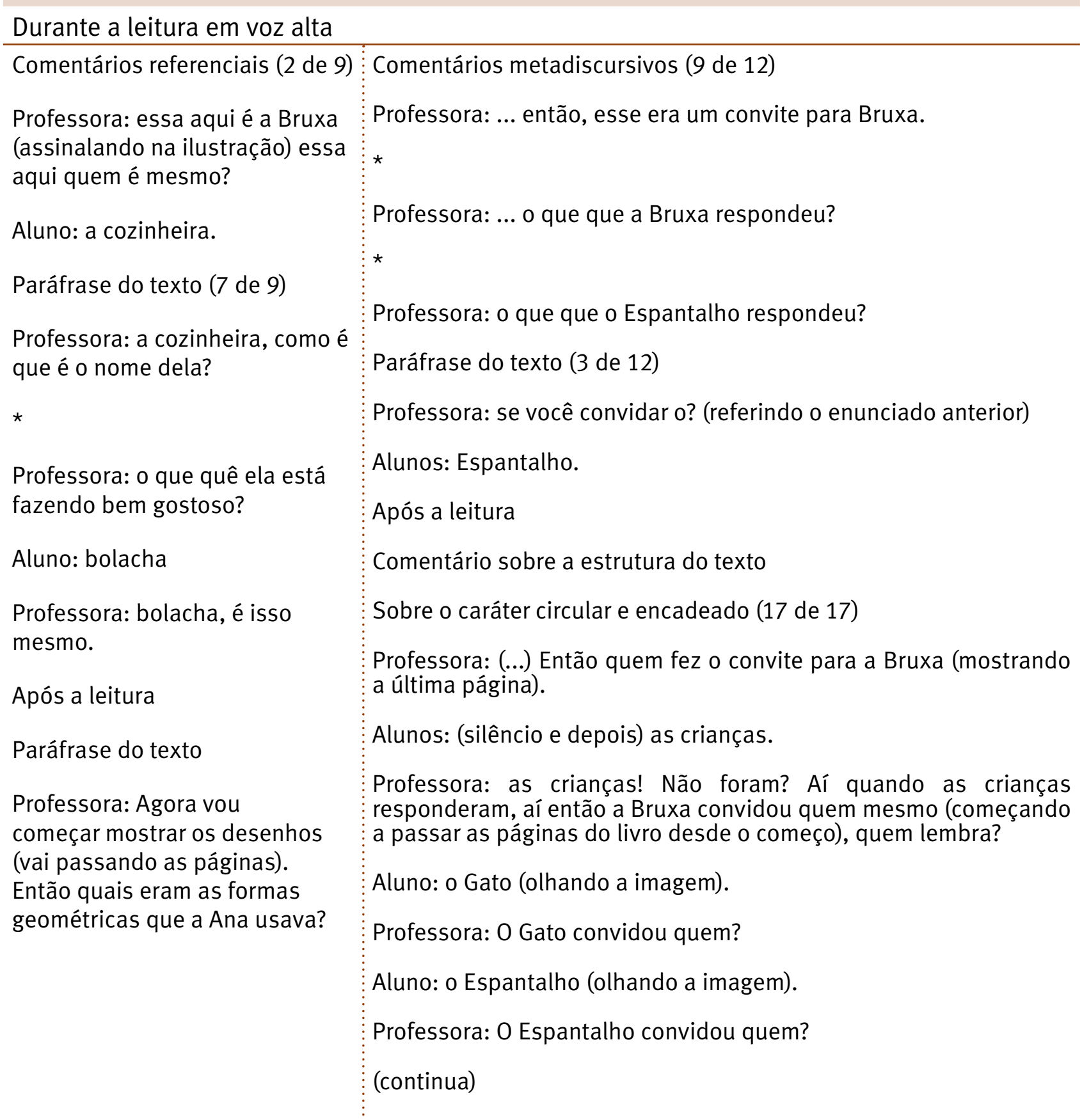




\section{PROFESSORA 4}

Durante a Leitura A, não houve referências ao texto. Após a leitura, a professora realizou e estimulou a paráfrase do texto, também formulou comentários referenciais. Durante a Leitura $B$, como se observa na tabela, os comentários foram poucos e quase que cada um cumpriu uma função diferente: estimular a repetição de parte do texto lido; referir algum aspecto da ilustração; denominar atos enunciativos e fazer referência à relação do texto lido com outro do repertório de textos conhecidos.

Tabela 13. Exemplos da análise da fala sobre textos. Professora 4

\section{PROFESSORA 4}

Leitura A. A fada Sofia.

Leitura B. Bruxa, Bruxa, venha à minha festa.

Durante a leitura em voz alta

Após a leitura

Paráfrase do texto (10 de 15).

Professora: Então tá falando de quem? De uma...

Alunos: fada (coro).

Professora: qual é o nome dessa fada?

Alunos: Sofía (coro).

Professora: Sofía (repetindo). E o que que a Sofía faz de legal?

Alunos: mágicas.

Professora: mágicas, né? E ela usa o que para fazer as mágicas?

Alunos: varinha.

Comentários referenciais (5 de 15)

Professora: tem um vestido colorido, bem bordadão, bem colorido. E que é o que tem na mãozinha dela? O que leva?

Paráfrases do texto (1 de 5)

Professora: ... então, vai convidar quem?

Comentários referenciais (2 de 5)

Professora: ... olha o dragão, né?

Comentário metadiscursivo (1 de 5)

Professora: vamos fazer o convite do Espantalho. Espantalho, Espantalho, por favor, venha à minha festa.

Após a leitura

Comentário intertextual (1 de 5)

Professora: mas nesta história o Lobo não vai comer Chapeuzinho Vermelho.

Sobre o caráter circular do texto

Professora: e ai começa de novo, né? Bruxa, Bruxa, por favor, venha à minha festa.

Comentário interpretativo (4 de 5)

Professora: de quem que era a festa?

Alunos: da Bruxa

Professora: e a Bruxa, de novo, convidou um monte de gente, né?

Alunos: Sim.

Professora: e quem as crianças convidaram por último?

Alunos: A Bruxa.

Professora: então convidou um monte de gente. 
Em síntese, a análise anterior mostra que de uma leitura a outra mudou a linguagem usada para falar a respeito do texto lido. As professoras passaram de uma enunciação quase que exclusivamente referencial e reprodutiva a uma linguagem utilizada para comentar diferentes aspectos do texto: o tipo de enunciados contidos (convites e respostas); a sua estrutura (circular, encadeada); ou o seu caráter intertextual. Além destes comentários, registraram-se outros, que retomavam o conteúdo do texto ou para formular conjecturas (comentários conjecturais) ou para explicitar seu significado (comentários interpretativos).

Essa mudança pode relacionar-se com a alusão constante, feita no Caderno de Orientações, à construção de conversas a partir e a propósito do livro. A maioria dos enunciados estudados nesta análise não corresponde diretamente a nenhuma das ações propostas (de forma explícita) pelas orientações. Contudo, são consequência das mesmas e também das características do livro.

\section{CONSIDERAÇÕES FINAIS}

O objetivo desta pesquisa foi começar a indagar acerca do impacto dos materiais distribuídos pelo MEC com a intenção de promover práticas letradas nos processos de alfabetização inicial, em particular práticas baseadas na leitura de livros de literatura infantil. Tal propósito exigiu estabelecer um ponto de partida, um antes que pudesse ser comparado com os desempenhos promovidos pelos materiais educativos introduzidos. Por isso, foi necessário identificarquais eram as práticas alfabetizadoras das professoras participantes e, também, caracterizar a atividade de leitura de livros de literatura infantil na sala de aula.

Os resultados da caracterização inicial das práticas desenvolvidas usualmente pelas professoras participantes revelaram que todas utilizam métodos fônicos e silábicos na sua prática pedagógica; as atividades recorrentes consistem em tarefas de cópia, ditado da professora às crianças e leitura individual e coletiva de sílabas e palavras. Quanto à atividade de leitura de livros de literatura infantil, as professoras faziam uma leitura em voz alta, a maior parte do tempo de forma contínua, com escassas interrupções para controlar a atenção dos alunos ou para fazer comentários referenciais.

A escolha dos livros sugere que as professoras não tinham critério definido. Em um dos casos observados, o critério pode ter sido prático (texto curto, contido em ficha de exercícios); nos outros três, parece ter sido a disponibilidade dos 
livros na sala. A ausência de uma intencionalidade de ensino específica se verificou no fato de que as formas e os conteúdos do livro/texto não foram referidos, comentados, nem usados, de nenhum modo, para ensinar alguma coisa em particular (vocabulário, formas de expressão, conceitos, etc.).

Quantoaodiscursosobreostextos, afala dasprofessorasfoipredominantemente referencial; denominando aspectos da imagem ou estimulando denominações por parte dos alunos. Essa característica foi evidente no recurso constante aos demonstrativos (esse, aqui). Além disso, as perguntas formuladas geralmente foram fechadas e não retomavam, questionavam ou estendiam as respostas infantis. Nessa leitura a finalidade predominante se centrou no aspecto lúdico; depois da leitura as professoras estimularam comentários avaliativos gerais, pedindo aos alunos que dissessem se gostaram ou não da história.

Em síntese, essa caracterização inicial sugeriu que as professoras não utilizavam intencionalmente a leitura de livros de literatura infantil nos processos de alfabetização inicial. Além disso, é necessário destacar que se trata de um grupo de professoras com estilos transmissivos, que desenvolvem práticas na sala de aula que não têm o aluno como ponto de partida, eles são receptores das suas explicações e pedidos. Esse aspecto é importante porque revela uma concepção dos processos de ensino e aprendizagem oposta às propostas divulgadas nos materiais educativos para a alfabetização distribuídos pelo MEC.

No entanto, os resultados obtidos a partir do uso dos materiais educativos entregues sugerem que tais materiais podem melhorar este tipo de práticas alfabetizadoras. As análises realizadas revelaram mudanças importantes no discurso das quatro professoras observadas. Uma das mudanças consistiu em estimular a participação das crianças durante a leitura; com isso, as professoras conseguiram realizar verdadeiras leituras compartilhadas. Outra mudança importante consistiu na passagem do uso de uma linguagem quase que exclusivamente referencial, de denominação de aspectos da ilustração, à realização de verdadeiros comentários metatextuais (comentários sobre enunciados textuais e sobre a estrutura e o significado do texto).

Contudo, os estilos interativos professora-criança se mantiveram. Os registros iniciais mostraram, por um lado, a predominância de estilos transmissivos com tendências ou mais diretivas (P2 e P4) ou mais interativas (P1 e P3). E mesmo as professoras com um estilo mais interativo, embora concedessem a palavra aos alunos, não trabalhavam a partir das suas participações, não 
retinham, nem analisavam, nem estendiam suas produções. Esse aspecto não foi objeto de uma análise específica e deveria ser considerado em futuras pesquisas, porque nele se concretizam as representações dos professores sobre os processos de ensino e aprendizagem e, em particular, sobre o seu papel na aprendizagem das crianças.

Outro aspecto que chama a atenção é a escassa análise por parte das professoras dos conhecimentos infantis e das oportunidades de ensino que muitas das atividades propostas oferecem. Destaca-se a escassa orientação do trabalho didático para o desenvolvimento de conhecimentos e habilidades na produção oral e escrita. Por exemplo, o caráter repetitivo da história lida facilitou que as crianças decorassem o texto, porém esse conhecimento não foi aproveitado para propor tarefas de escrita, como, por exemplo, a escrita autônoma da lista dos personagens, ou a reescrita de partes ou da totalidade do texto (considerando que a maioria dos alunos escreve alfabeticamente), como o sugere o material. Esse aspecto revela a limitada compreensão por parte das professoras das relações entre a oralidade e a leitura e a escrita, e entre a compreensão e a produção da linguagem.

Neste artigo se documentou uma primeira experiência na compreensão e uso de um exemplar de um dos Materiais Complementares, distribuídos pelo MEC, por parte de quatro professoras de um município de Mato Grosso. Os instrumentos e as análises utilizadas mostraram-se apropriadas para indagar a respeito do impacto destes materiais nas práticas de alfabetização que efetivamente se realizam nas aulas. Em particular, a análise do discurso sobre os textos, ou fala sobre os textos, se revelou sensível às diferenças.

A principal dificuldade observada se relaciona com as representações das professoras sobre os processos de ensino e aprendizagem. As concepções poucoconstrutivassobreosprocessos deaprendizagem limitaramosresultados que podiam ser obtidos com o uso dos materiais e atividades propostas. Esse fator não constituía um objetivo de estudo nesta pesquisa, porém se revelou como um aspecto chave para a interpretação dos resultados, por isso, avaliamos que será uma das variáveis a serem consideradas em pesquisas futuras. Uma das perguntas a ser analisada será: as propostas contidas nos materiais complementares podem influir nas concepções dos professores sobre os processos de ensino e aprendizagem? E mais especificamente, nas concepções sobre os processos de ensino e aprendizagem alfabéticos?

Outra limitação se relacionou com o caráter transversal da observação realizada; nesse sentido, seria interessante indagar se a prática repetida 
do tipo de atividades propostas, melhora a compreensão das mesmas.As professoras conseguiriam seguir melhor as orientações na segunda ou terceira vez que desenvolvessem o mesmo tipo de atividades?

No contexto do Pacto Nacional pela Alfabetização na Idade Certa respostas a todas essas questões podem oferecer informações úteis na busca de melhores condições de alfabetização das crianças. 


\title{
Incorporation of writing practices in literacy
}

\begin{abstract}
This study documents understanding and use of materials by four literacy teachers of material distributed by the Ministry of Education for teaching basic reading, writing and speech skills. An initial profile of the teachers showed that they had little understanding of the conceptual challenges that written culture encompasses. The results gained using these educational materials suggest that they can contribute to improving literacy practices. Analyses done have shown major changes in the discourse used by these four teachers, with the main difficulty found being related to their depictions of teaching and learning processes. Minimally constructive ideas about learning processes limited the results that could be achieved using the supplementary material distributed by the Ministry of Education.
\end{abstract}

Keywords: Writing practices. Literacy. Supplementary materials. 


\section{REFERÊNCIAS}

AMERICAN SPEECH-LANGUAGE-HEARING ASSOCIATION (ASHA). Roles and responsibilities of speech-language pathologists with respect to reading and writing in children and adolescents. Disponivel em: http://www.asha.org/ policy/PS2001-00104/. Acesso: em junho de 2013.

AYRA, P. et al. Reclaiming literacy instruction: evidence in support of literaturebased programs. Language Arts. v. 83, n. 1, p. 63-72, 2005.

BRASIL.Ministério de Educação. Trilhas. São Paulo, SP: Ministério de Educação, 2011.

BRASIL. Ministério de Educação. Portaria № 867, de 4 de julho de 2012. Institui o Pacto Nacional pela Alfabetização na Idade Certa e as ações do Pacto e define suas diretrizes gerais. Diário Oficial da União, Brasília, nํ129, p. 22, jul. 2012.

COLL, C. et al. Actividad conjunta y habla: una aproximación al estudio de los mecanismos de influencia educativa. In: BERROCAL, P.F.; MELERO, M. (Ed.). La interacción social en contextos educativos. Madrid: Siglo XXI, 1995. p. 194-326.

FERREIRO, E. Acerca de las no previstas pero lamentablesconsecuencias de pensar solo em La lectura y olvidar la escritura cuando se puede formar al lector. In: COLOMER, T.; FERREIRO, E.; GARRIDO, F.. Lecturas sobre lecturas/3. México, D.F.: Conaculta (Dirección General de Publicaciones), 2001. p. 31-37. (Ponencia presentada em El Seminario Internacional ¿Qué y por quéestánleyendolosniños y jóvenes de hoy?Feria Internacional de Libro Infantil y Juvenil de laciudad de México).

HEATH, B. Ways with words. In: INTERNATIONAL READING ASSOCIATION AND NATIONAL ASSOCIATION FOR THE EDUCATION OF YOUNG CHILDREN (IRA/ NAEY) Learning to read and write: developmentally appropriate practices for young children. Newark, DE: International Reading Association, 1986.

INTERNATIONAL READING ASSOCIATION AND NATIONAL ASSOCIATION FOR THE EDUCATION OF YOUNG CHILDREN (IRA AND NAYEC). Learning to Read and Write: Developmentally Appropriate Practices For Young Children. Newark, DE: International Reading Association, 1998.

NATIONAL COUNCIL OF TEACHERS OF ENGLISH (NCTE). On Reading, Learning to Read, And Effective Reading Instruction: an overview of what we know 
and how we know it. 2004. Disponível em: http://www.ncte.org/positions/ statements. Acesso em junho de 2013.

OLSON, D. El mundo sobre el papel. Barcelona: Gedisa, 1994. - La cultura escrita como actividad metalinguística. In: OLSON, D.; TORRANCE, N. (Ed.). Cultura escrita y oralidad. Barcelona: Gedisa, 1998. p. 333-358.

A theory of reading/writing: from literacy to literature. Writing Systems Research, n. 1, v.1, p. 51-64, 2009.

OLSON, D.; ASTINGTON, J. Talking about text: how literacy contributes to thought. Journal of Pragmatics, v. 14, p. 705-721, 1990.

ONG, W. Oralidad y Escritura. Tecnologías de lapalabra. México: Fondo de Cultura Económica, 1987.

SEPÚLVEDA, A.; TEBEROSKY, A. El lenguajeen primer plano enla literatura infantil para laenseñanza y elaprendizaje inicial dellenguaje escrito. Cultura y Educación, v. 23, n. 1,p. 23-42, 2011.

SILVA, C.; CAFIERO, D. Implicações das políticas educacionais no contexto do ensino fundamental de nove anos. Educação em revista, v. 27, n. 2, p. 219248, 2011.

TEBEROSKY, A. Aprendiendo a escribir. Barcelona: Horsori, 1993.

. Proposta constructivista per aprendre a llegir i a escriure. Barcelona: Vicens Vives, 2001.

. El texto em laalfabetización inicial. Infancia y Aprendizaje, v. 2, n. 32, 199-218, 2009.

Desde la literatura al aprendizajedellenguaje y su escritura. Actas Del Simposio Internacional La literatura que Acoge: infancia, inmigración y lectura. Organizado por el Grupo de Investigación de Literatura Infantil y Juvenil y EducaciónLiterariadel Departamento de Didáctica de laLengua, de la Literatura y de lasCienciasSociales de laUniversidad Autónoma de Barcelona. Disponivel em: http://www.aprendretextos.com/. Acesso em junho de 2011.

TEBEROSKY, A.; SEPÚLVEDA, A. La literatura enlaalfabetizacióninicial. Actas V Congreso Internacional de Psicología y Educación: los retos del futuro. Oviedo: Universidad de Oviedo, 2008. 
TOMASELLO, M. The cultural origins of human cognition. Cambridge: Harvard University Press, 1999.

WATSON, R. Talk about text: literate discourse and metaliterate knowledge. In: REEDER, K. et al. (Ed.). Literate apprenticeships: the emergence of language and literacy in the preschool years. New Jersey: Ablex Publishing, 1996. p. 81-100. _. Literacy and oral language: implications for early literacy acquisition. In: NEUMAN, S. B.; DICKINSON, D.K. (Ed.). Handbook of Early Literacy Research. New York: The Guilford Press, 2002. p. 43-65.

RECEBIDO: Dezembro de 2012.

APROVADO: Abril de 2013. 
ANEX01. EXEMPLO DE ESTRUTURA DAS ATIVIDADES PROPOSTAS AO PROFESSOR NO CAderno de ORIENTAÇões: histórias COM REPETIÇÃo

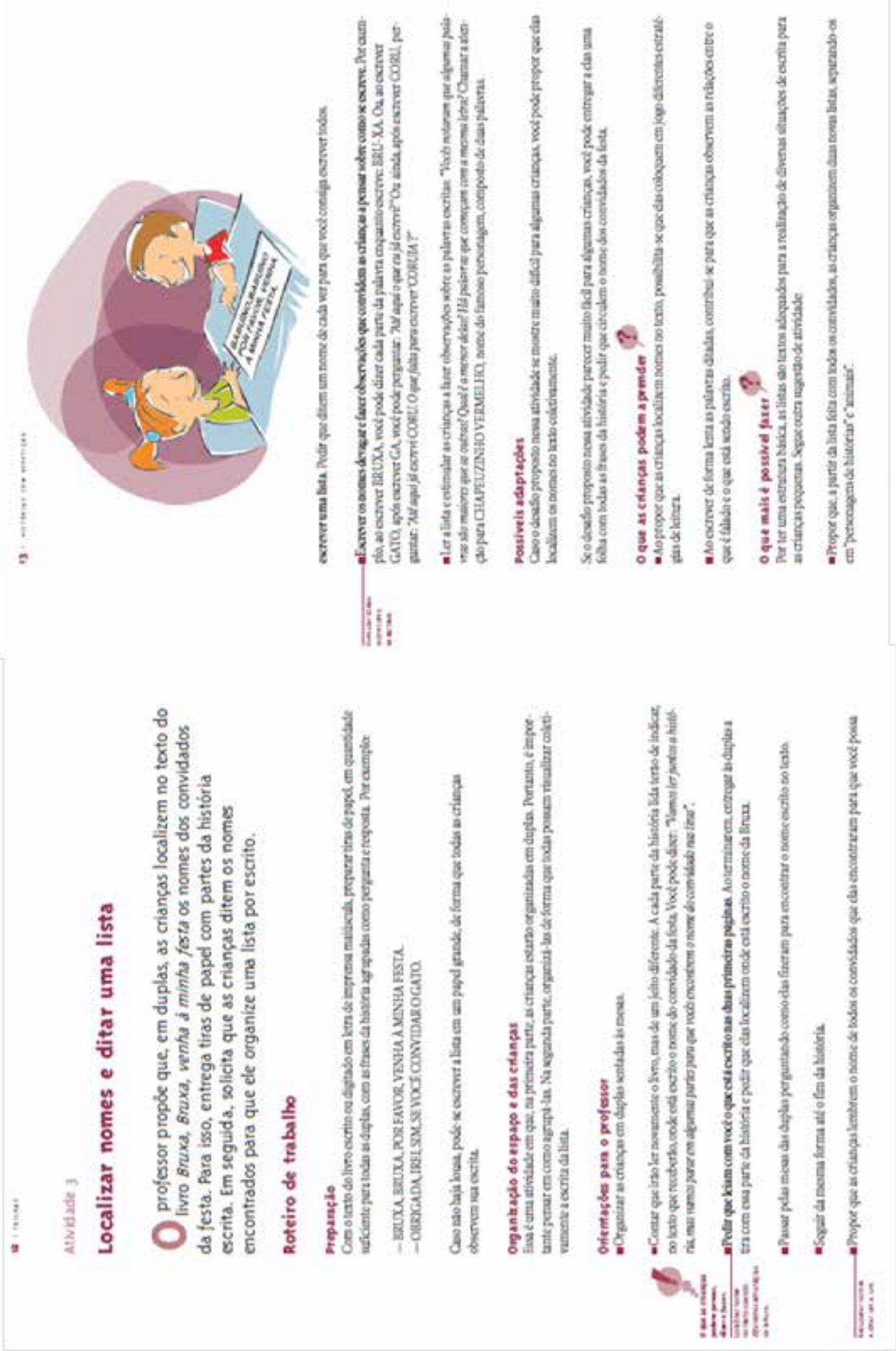

